\title{
Carbohydrate Yield and Biomethane Potential from Enzymatically Hydrolysed Saccharina latissima and Its Industrial Potential
}

\author{
Jacob J. Lamb1,2*, Dag R. Hjelme1, Kristian M. Lien² \\ ${ }^{1}$ Department of Electronic Systems \& Enersense, NTNU, Trondheim, Norway \\ ${ }^{2}$ Department of Energy and Process Engineering \& Enersense, NTNU, Trondheim, Norway \\ Email: ^jacob.j.lamb@ntnu.no
}

How to cite this paper: Lamb, J.J., Hjelme, D.R. and Lien, K.M. (2019) Carbohydrate Yield and Biomethane Potential from Enzymatically Hydrolysed Saccharina latissima and Its Industrial Potential. Advances in Microbiology, 9, 359-371. https://doi.org/10.4236/aim.2019.94021

Received: March 22, 2019

Accepted: April 16, 2019

Published: April 19, 2019

Copyright $\odot 2019$ by author(s) and Scientific Research Publishing Inc. This work is licensed under the Creative Commons Attribution International License (CC BY 4.0).

http://creativecommons.org/licenses/by/4.0/

c. (i) Open Access

\begin{abstract}
The demand for fuel for utilisation of machinery and transport has culminated in large amounts of fossil fuel usage in the last century. The environmental dangers attached with the usage of fossil fuels have created a large demand for alternative sources of fuels. There is an array of polysaccharides contained within macroalgae, such as mannitol, cellulose and laminarin. These polysaccharides have potential for production of alternative biofuels; however, they are not easily accessible for biological digestion. By pretreatment of macroalgae with enzymes, these polysaccharides may be easier to access by microbes, allowing effective utilization in anaerobic digestion. Saccharina latissima, available in abundance on the Norwegian coast line, is a brown macroalgae with a high level of carbohydrates. This study assesses the ability for utilisation of enzymatically pre-treated Saccharina latissima for production of biogas through anaerobic digestion. The harvested Saccharina latissima was analysed to contain $30.11 \pm 2.30 \mathrm{~g}$ of reducing sugars per $100 \mathrm{~g}$ of dry sample upon enzymatic hydrolysis. This was able to yield $459 \pm 30 \mathrm{~mL}$ per gVS of biogas through anaerobic digestion, with a methane content of $56 \%$. This suggests a biomethane potential of $1760 \mathrm{~m}^{3}$ per ha of productive sea floor growing Saccharina latissima. An evaluation of this process has been performed to demonstrate the industrial potential of Saccharina latissima in biogas production.
\end{abstract}

\section{Keywords}

Macroalgae, Hydrolysis, Biogas, Biomethane, Enzymatic Hydrolysis

\section{Introduction}

The development of alternative fuels to reduce the requirement of fossil fuel us- 
age have become of increased interest in recent decades; however, the production of alternative fuels like biofuels is economically unfavourable compared to the fossil fuel market. Despite this, many biofuels (e.g., bioethanol, biogas and biodiesel), are promising alternatives due to their potential sustainability and low environmental impact [1] [2] [3] [4]. Furthermore, many of these biofuels can be utilised by conventional means (e.g., internal combustion engines) when supplimented with fossil fuels [5]. Biogas is a renewable fuel that is already utilised globally as an alternative to fossil fuels, being able to be injected directly into pre-existing natural gas networks. Currently, the majority of biogas production relies on the utilisation of biological waste products as the substrate (e.g., agricultural waste \& food industry waste), meaning for many years it has been considered a waste-to-energy route. Although there is still opportunity for significant increases in production from these waste products, other areas of unutilised biomass are of increased interest to extend from the waste-to-energy capacity, and towards a more global and high capacity model. Furthermore, to avoid utilisation of substrates that compete with food crops and require large amounts of land area [6] [7], unused biomass is of great interest, avoiding obstacles such as limited yields, geographic latitude, structural characteristics and high production costs [8].

An alternative is to utilise marine biomass as a substrate, avoiding many of the problems observed in terrestrial substrates. Macroalgae are photosynthetic organisms that utilise the solar irradiation to fix carbon for their metabolism forming rigid polysaccharide-based structures. They grow wild throughout the oceans on coastal areas, collecting significant quantities of polysaccharides that can be hydrolysed into simple polysaccharides for straight-forward utilisation in anaerobic digestion. Additionally, macroalgae tend to have a high content of solids ranging between $8.3 \%-22 \%$ [9] [10] [11], reducing the requirement of thickening, dewatering and drying of the substrate. Macroalgae have a large area of productivity globally, high production rates per area (Table 1), do not compete with conventional food-based agriculture, do not require fertilization or irrigation, recycle ocean bicarbonate and are compatible with existing production streams and biorefineries [12] [13] [14]. The main drawback currently is the saccharification of microalgal biomass into anaerobically digestible polysaccharides for significant biogas production.

Table 1. Major bioethanol crops and macroalgae comparison (modified from $(17,36)$ ).

\begin{tabular}{ccc}
\hline Substrate & $\begin{array}{c}\text { Average yield } \\
\text { (kg ha year) }\end{array}$ & $\begin{array}{c}\text { Dry weight of hydrolysable } \\
\text { carbohydrates (kg ha year) }\end{array}$ \\
\hline Wheat (grain) & 2800 & 1560 \\
Maize (kernel) & 4815 & 3100 \\
Sugar beet & 47,070 & 8825 \\
Sugar cane & 68,260 & 11,600 \\
Macroalgae $(17,31)$ & 75,000 & 4500 \\
\hline
\end{tabular}


There is a significant lack of terrestrial agriculture production in Nordic countries due to the winter climate (low temperatures and light levels), where the production of biomass on land is a slow process. Here, the potential of food production from terrestrial agriculture cannot be reduced for production of biomass for biofuels. In these cases, macroalgae provide a significant alternative as a biomass source. The extensive coastline of Norway is a prime example, where the warm waters from the gulf stream provide the perfect growing conditions for macroalgae like Saccharina latissima, a carbohydrate-rich macroalge [15] [16]. S. latissima contains the carbohydrates laminarin, mannitol and alginate in significant quantities, where laminarin and manitol serve as energy storage carbohydrates, and alginate as a rigid structural carbohydrate. Although laminarin and mannitol can be anaerobically digested by various microbes to produce biogas, alginate is rather challanging to hydrolyse, reducing its digestability during biogas production.

Here, samples of $\mathcal{S}$. latissima that were obtained from Trondheimsfjord in Norway have been assessed for their biogas production potential from there digestable carbohydrates. Using a carbohydrate extraction proceedure previously described [17], further easily digestable carbohydrates were obtained from the macroalgae. This allowed to biogas potential of $S$. latissima to be significantly increased, providing the foundation for its utilisation in the biogas industry in the Nordic countries.

\section{Materials and Methods}

\subsection{Macroalgae Collection}

S. latissima was collected from Trondheimsfjord (N63 $\left.26^{\prime} 56^{\prime \prime}, \mathrm{E} 10^{\circ} 10^{\prime} 48^{\prime \prime}\right)$ near Trondheim, Norway in August of 2017. The macroalgae were subsequently washed using tap water to remove particulates from the surface. S. latissima was then milled using a table-top blender with $10 \mathrm{~mL}$ of deionized water per $1 \mathrm{~kg}$ of macroalgae to produce a dense macroalgae pulp. The pulp was dried for $48 \mathrm{~h}$ at $30^{\circ} \mathrm{C}$ and then stored in airtight plastic bags in a dry location for further use.

\subsection{Algal Pulp Lysis}

The dry macroalgae pulp $(10 \% \mathrm{w} / \mathrm{v})$ was suspended in $0.15 \mathrm{M}$ sodium carbonate $\left(\mathrm{Na}_{2} \mathrm{CO}_{3}\right)$ solution to a volume of $1 \mathrm{~L}$ at a starting $\mathrm{pH}$ of 9.0 in a stirred beaker for $2 \mathrm{~h}$ at $50^{\circ} \mathrm{C}$.

\subsection{Enzymatic Hydrolysis}

Commercial $\beta$-glucanase (G4423) from Trichoderma longibrachiatum (Sigma Aldrich, Germany) was used during enzymatic hydrolysis. This was an enzymatic mixture of $\beta$-1-3/1-4-glucanase, xylanase, cellulase, $\beta$-glucosidase, $\beta$-xylosidase, $\alpha$-L-arabinofuranosidase and amylase activities. The lysed algal pulp was adjusted to $\mathrm{pH} 6$ using $\mathrm{HCl}$ acid solution. Then $5 \mathrm{mg}$ of enzyme mix per $\mathrm{g}$ of macroalgae dry weight was added to the solution, and left in the stirred flask for 
$48 \mathrm{~h}$ at room temperature. Samples were taken every $12 \mathrm{~h}$ and analyzed for glucose concentration using a hexokinase glucose assay kit (GAHK20-1KT, Sigma, Germany).

\subsection{Carbohydrate Characterization}

Total carbohydrates, reducing sugar and glucose content were both determined by acidic treatment of pre-hydrolysis dry biomass. Biomass $(0.5 \mathrm{~g})$ was treated with $5 \mathrm{~mL}$ of $72 \%(\mathrm{v} / \mathrm{v}) \mathrm{H}_{2} \mathrm{SO}_{4}$ at room temperature for 30 minutes with constant stirring via a magnetic stirrer. The sample was then diluted to a volume of $50 \mathrm{~mL}$ with deionized water, then autoclaved at $121^{\circ} \mathrm{C}$ for 30 minutes. Once cooled, $\mathrm{NaOH}$ was added to the sample to reach a $\mathrm{pH}$ of 7.5. The total carbohydrates in the sample were then determined by using a phenol-sulfuric acid method [18]. Reducing sugars in the sample were determined using a dinitrosalicylic acid method [19]. Glucose content of the hydrolysate was determined using a hexokinase glucose assay kit (GAHK20-1KT, Sigma, Germany).

\subsection{Inoculum}

The microbial inoculum for the biomethane potential experiments was obtained from the Biokraft biogas plant (Skogn, Norway), from a large-scale continuous mesophilic multifuel anaerobic digester. Prior to the biomethane potential test, the inoculum was incubated at $39^{\circ} \mathrm{C}$ to reduce endogenous biogas production. The inoculum was diluted to $9 \mathrm{~g}$ volatile solids (VS) per liter. The diluted inoculum had a $\mathrm{pH}$ of 7.5 .

\subsection{Biomethane Potential}

The processed samples were digested anaerobically in sealed batch bottles. These were performed in triplicate with inoculum and processed samples, with inoculum alone as a control batch. The following was added as trace minerals and nutrients: $10 \mathrm{mM} \mathrm{NH}_{4} \mathrm{Cl}, 8 \mathrm{mM} \mathrm{NaCl}, 1 \mathrm{mM} \mathrm{CaCl} \cdot 2 \mathrm{H}_{2} \mathrm{O}, 0.5 \mathrm{mM} \mathrm{MgCl} \cdot 6 \mathrm{H}_{2} \mathrm{O}$ and $0.3 \mathrm{mM} \mathrm{Na}_{2} \mathrm{~S} \cdot 3 \mathrm{H}_{2} \mathrm{O}$, as previously described [20]. The final liquid volume of each experiment was $250 \mathrm{~mL}$. The bottles were flushed with nitrogen gas and closed with rubber septums and sealed as described by Ekstrand et al. [21]. These were incubated at $39^{\circ} \mathrm{C}$ indefinitely with regular agitation.

\subsection{Composition Analysis}

Analysis of the dry matter (DM) and volatile solids (VS) we performed on the steam exploded birch wood and inoculum before further experimentation using standard methods [22]. The dry matter was determined by incubation of the birch wood and inoculum at $105^{\circ} \mathrm{C}$ for $24 \mathrm{~h}$. The mass of the samples after the incubation was compared to the mass pre incubation to acquire a percentage of $\mathrm{DM}$. New samples were then incubated at $550^{\circ} \mathrm{C}$ for 4 hours in a muffle furnace. The weight of the samples after incubation in the muffle furnace were compared to the weight of the sample before incubation to acquire a percentage of VS. The DM was determined to be $14.63 \%$; whereas, the VS was determined to be $9.13 \%$. 


\subsection{Gas Production Volume}

Measurement of the produced gas volume was achieved using an optimised liquid displacement method. The volume of gas was then adjusted for temperature using Charles's law.

\subsection{Gas Composition and Calculation}

Regular $10 \mathrm{~mL}$ samples of gas from each experiment were extracted for compositional analysis. The composition was analysed using gas chromatography (SRI 8610C, SRI Instruments, USA), equipped with a thermal conductivity detector using hydrogen as the carrier gas. A standard mixture of $\mathrm{CO}_{2}, \mathrm{CH}_{4}, \mathrm{H}_{2}$ and $\mathrm{N}_{2}$ was used as a calibrating gas. Using the volume of gas calculated with the liquid displacement method, and the percentage of methane present in the samples, methane production was calculated for the experiments. All methane production levels are the average of 3 separate experiments and have been corrected by subtracting the endogenous methane production levels for the inoculum only experiments.

\subsection{Statistical Data Analysis}

All experiments within this study were conducted in triplicate with the results displayed as mean values \pm the standard deviation.

\section{Results}

S. latissima is a naturally occuring macroalgae that has a fast growth rate and is found in many locations on the extensive Nordic coastline. With increasing demand for substrates for biomethane production, it seems logical to utilise this macroalgae due to the considerable amounts of carbohydrates it produces. By exposing the microalgae to an enzymatic hydrolysis pre-treatment, the increases in straight forwardly digestable carbohydrates is of great interest to the biogas industry.

\subsection{S. latissima's Carbohydrate Content}

Using the collected samples of $S$. latissima, the total carbohydrates, reducing sugars and the glucose yield were determined (Table 2). These observations are similar to those previously obtained using the same methodology [17]. Before the enzymatic hydrolysis, the total carbohydrates consisted of $55 \% \pm 3.1 \%$ of the dry weight of $S$. latissima. Furthermore, the reducing sugar content was $36 \% \pm$ $1.9 \%$ of the dry weight, whereas the glucose content was $10 \% \pm 1.8 \%$ of the dry weight of $S$. latissima. These observations of carbohydrate composition are in agreement with previously observed compositions of $S$. latissima, including studies of S. latissima obtained from Trondheimsfjorden [17] [23] [24] [25].

\subsection{Enzymatic Hydrolysis of Polysaccharides from S. latissima}

During a $2 \mathrm{~h} \mathrm{basic} \mathrm{(pH} \mathrm{9)} \mathrm{lysis} \mathrm{method} \mathrm{at} 50^{\circ} \mathrm{C}$ in a $0.15 \mathrm{M} \mathrm{Na}_{2} \mathrm{CO}_{3}$ solution, the 
polysaccharides from $S$. latissima were extracted. The lysate was then altered to a neutral $\mathrm{pH}(\mathrm{pH} 6)$ and exposed to an enzyme mixture of $\beta-1-3 / 1-4$-glucanase, xylanase, cellulase, $\beta$-glucosidase, $\beta$-xylosidase, $\alpha$-L-arabinofuranosidase, and amylases for a period of $48 \mathrm{~h}$ at room temperature. The reducing sugar concentration of the sample was measured every $12 \mathrm{~h}$ during the enzymatic hydrolysis process.

From the initial basic lysis of $S$. latissima, $8.37 \pm 0.53 \mathrm{~g} / \mathrm{L}$ of reducing sugars were released. Further enzymatic hydrolysis yielded a further $21.74 \pm 1.77 \mathrm{~g} / \mathrm{L}$ of reducing sugars after the $48 \mathrm{~h}$ incubation period (Figure 1; Table 3). The total reducing sugars obtained from the basic lysis and enzymatic hydrolysis was observed to be $30.11 \pm 2.30 \mathrm{~g} / \mathrm{L}$ of reducing sugars. When using the dinitrosalicylic acid method for determining total reduced sugars [19], the maximum amount of reducing sugars obtainable from the sample of $S$. latissima was observed to be $36 \% \pm 1.9 \%$ of the dry weight of reducing sugars before the lysis and enzymatic hydrolysis. Therefore, the efficiency of this process was determined to be $83.6 \%$ of the maximum obtainable reducing sugars, which is in agreement with previously observed results [17].

With regard to the rate of the enzymatic hydrolysation of the polysaccharides from $S$. latissima, the maximum rate was observed at $12 \mathrm{~h}$ of incubation with the enzyme mixture (Figure 2; Table 3 ). The rate gradually declined after this period, as typically observed in similar studies [12] [17] [26] [27]. Although it has been speculated that the decline in rate of the enzymatic hydrolysis may be due to the inhibition of the enzymes by the liberated glucose and cellobiose [12] [27] [28], it may also be due to the reduction of functional enzyme units in relation to the reduced amount of complex polysaccharides left.

Table 2. Carbohydrate composition of S. latissima.

\begin{tabular}{cc}
\hline $\begin{array}{c}\text { Carbohydrate } \\
\text { group }\end{array}$ & $\begin{array}{c}\text { Relative \% of } \\
\text { dry weight }\end{array}$ \\
\hline Total carbohydrate & $55 \pm 3.1$ \\
Total reducing sugar & $36 \pm 1.9$ \\
Glucose (pre hydrolysis) & $10 \pm 1.8$ \\
\hline
\end{tabular}

Table 3. Hydrolysis yields from $S$. latissima.

\begin{tabular}{cccc}
\hline Time $(\mathrm{h})$ & $\begin{array}{c}\text { Total sugar } \\
\text { concentration }(\mathrm{g} / \mathrm{L})\end{array}$ & $\begin{array}{c}\text { Sugar released } \\
\text { via hydrolysis }(\mathrm{g} / \mathrm{L})\end{array}$ & $\begin{array}{c}\text { Saccharification } \\
\text { rate }(\mathrm{g} / \mathrm{L} / \mathrm{h})\end{array}$ \\
\hline 0 & $8.37 \pm 0.53$ & 0 & 0 \\
12 & $17.20 \pm 1.17$ & $8.83 \pm 0.64$ & $0.74 \pm 0.05$ \\
24 & $25.25 \pm 1.54$ & $16.88 \pm 1.01$ & $0.67 \pm 0.03$ \\
36 & $28.32 \pm 2.17$ & $20.95 \pm 1.63$ & $0.34 \pm 0.05$ \\
48 & $30.11 \pm 2.30$ & $21.74 \pm 1.77$ & $0.07 \pm 0.01$ \\
\hline
\end{tabular}




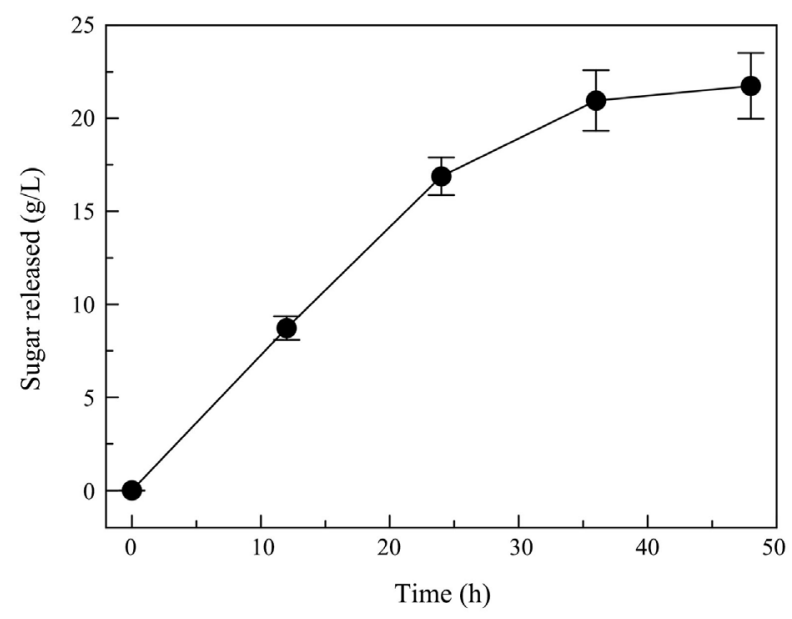

Figure 1. Enzymatic hydrolysis of carbohydrartes. Reducing sugars released from the enzymatically hydrolysed $S$. latissima over a $48 \mathrm{~h}$ incubation period in $\mathrm{g} / \mathrm{L}$. The experiment was produced in triplicate, and the results displayed are the mean values of the 3 replicates with their associated standard deviations as error bars.

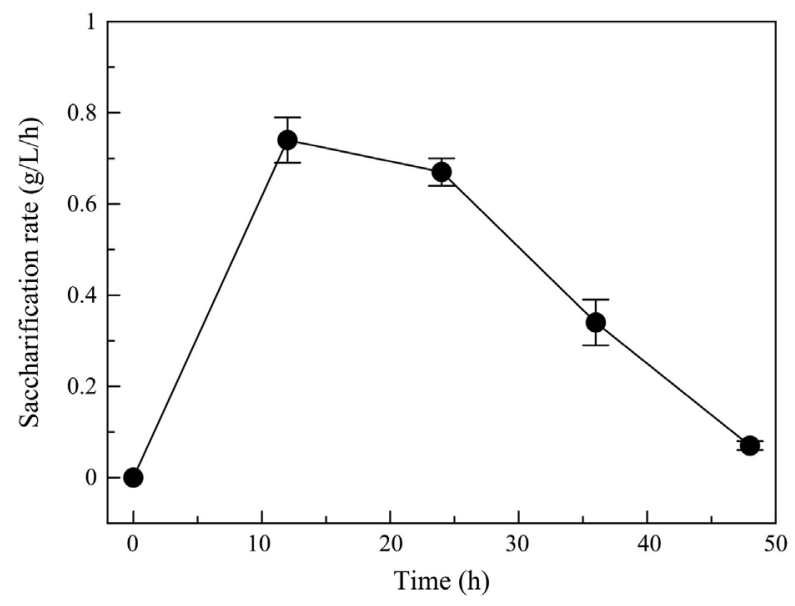

Figure 2. Saccharification rate during enymatic hydrolysis of $S$. latissima. The amount of reducing sugars per hour were measured to show the relative rate of saccharification. The rate is shown in $\mathrm{g} / \mathrm{L} / \mathrm{h}$ of reducing sugars yielded during the $48 \mathrm{~h}$ incubation period. The experiment was produced in triplicate, and the results displayed are the mean values of the 3 replicates with their associated standard deviations as error bars.

\section{Anaerobic Digestion of the Hydrolysate from S. latissima}

The anaerobic digestion of the hydrolysate from $S$. latissima was performed using inoculum from a biogas plant near Trondheim, Biokraft (Skogn, Norway). The sample was added in a 2:1 (VS/VS) ratio with the inoculum in $500 \mathrm{~mL}$ flasks sealed with rubber septums and flushed with nitrogen gas for 5 minutes to obtain an anaerobic environment. The bottles were then incubated at $39^{\circ} \mathrm{C}$ indefinately, with regular mixing. The biogas production was measured regularly using a liquid displacement method, and gas samples were assessed for composition using a GC machine (SRI 8610C, SRI Instruments, USA).

Two experiments were prepared for anaerobic digestion to determine the effect of the enzymatic hydrolysis on the amount of biogas produced; one with the 
lysed algal pulp without the enzyme hydrolysis step, and one with the lysed algal pulp with the enzyme hydrolysis step. The total biogas obtained from the anaerobic digestion of $S$. latissima algal pulp without enzyme hydrolysis was $372 \pm$ $22 \mathrm{~mL}$ per gVS. This is a similar biogas volume to previously observed values [20] [29] [30], but variation is expected due to seasonal and locational differences. Comparatively, the total biogas obtained from the anaerobic digestion of S. latissima S. latissima algal pulp with enzyme hydrolysis was $459 \pm 30 \mathrm{~mL}$ per gVS (Figure 3; Table 4). The gas contained $56 \% \mathrm{CH}_{4}$ as determined by GC, resulting in a biomethane production of $208 \pm 12$ and $257 \pm 17 \mathrm{~mL}$ per $\mathrm{gVS}$ for the algal pulp without and with enzyme hydrolysis, respectively (Figure 3; Table 4). Furthermore, the enzyme hydrolysis step was observed to increase the rate at which biogas was produced, reaching a near full digestion earlier than the algal pulp without the enzyme hydrolysis step.

\subsection{Future Industrial Biogas Production from S. latissima}

The results observed in this study of the anaerobic digestion of $S$. latissima show that the extraction of reducing sugars from $1 \mathrm{~kg}(\mathrm{w} / \mathrm{w})$ of the macroalgae yields $30.11 \pm 2.30 \mathrm{~g}$ of reducing sugars. The subsequent enzymatic hydrolysis allows the straight-forward anaerobic digestion of these carbohydrates into $459 \pm 30$ $\mathrm{mL}$ per gVS of biogas, resulting in $257 \pm 17 \mathrm{~mL}$ per gVS of biomethane from $S$. latissima. With respect to area required, as shown in Table 1, the amount of wet macroalgal biomass obtainable from 1 ha of sea floor is as high as 75,000 kg [31]. The VS of $S$. latissima was determined to be $9.13 \%$, resulting in $6847.5 \mathrm{kgVS}$ per ha. Therefore, 1 ha of $S$. latissima could potentially yield $3142 \mathrm{~m}^{3}$ of biogas, composed of $1760 \mathrm{~m}^{3}$ of biomethane. Therefore, the carbohydrate-rich macroalgae $S$. latissima has a large potential for utilisation as a substrate for biogas production. Furthermore, the utilisation of fresh water sources, fertilisers and terrestrial land is not required due to their ability to grow wildly in the Ocean.

Table 4. Biogas and biomethane yields from $S$. latissima.

\begin{tabular}{ccccc}
\hline Time (days) & Biogas $(\mathrm{mL} / \mathrm{gVS})$ & Biomethane $(\mathrm{mL} / \mathrm{gVS})$ & Biogas $(\mathrm{mL} / \mathrm{gVS})$ & Biomethane $(\mathrm{mL} / \mathrm{gVS})$ \\
\hline 0 & 0 & 0 & 0 & 0 \\
4 & $22 \pm 4$ & $12 \pm 2$ & $11 \pm 4$ & $6 \pm 2$ \\
7 & $78 \pm 6$ & $44 \pm 3$ & $44 \pm 4$ & $25 \pm 2$ \\
10 & $167 \pm 9$ & $93 \pm 5$ & $83 \pm 6$ & $47 \pm 3$ \\
14 & $257 \pm 17$ & $144 \pm 10$ & $141 \pm 13$ & $79 \pm 7$ \\
17 & $326 \pm 22$ & $182 \pm 13$ & $191 \pm 15$ & $107 \pm 8$ \\
20 & $385 \pm 31$ & $215 \pm 18$ & $213 \pm 26$ & $119 \pm 15$ \\
24 & $405 \pm 26$ & $227 \pm 15$ & $268 \pm 22$ & $150 \pm 12$ \\
27 & $420 \pm 28$ & $235 \pm 16$ & $292 \pm 22$ & $164 \pm 12$ \\
30 & $433 \pm 26$ & $242 \pm 15$ & $313 \pm 20$ & $175 \pm 11$ \\
34 & $440 \pm 33$ & $247 \pm 19$ & $335 \pm 24$ & $188 \pm 13$ \\
37 & $453 \pm 31$ & $254 \pm 18$ & $357 \pm 22$ & $200 \pm 12$ \\
40 & $459 \pm 30$ & $257 \pm 17$ & $372 \pm 22$ & $208 \pm 12$ \\
\hline
\end{tabular}




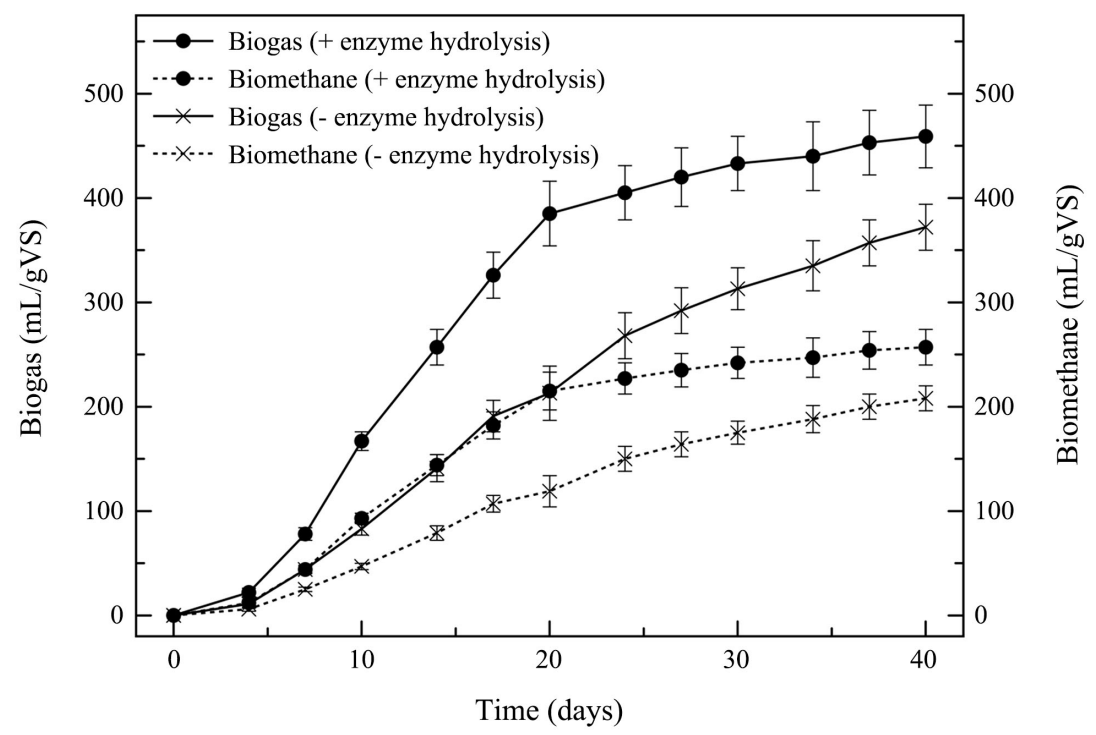

Figure 3. Biogas and Biomethane Potential. The potential of biogas and biomethane production was measured over a period of 40 days. The gas produced was then calculated for production per gVS. The solid lines represent the accumulative biogas production throughout the incubation in $\mathrm{mL} / \mathrm{gVS}$, whereas the dashed lines represent the biomethane content of this produced biogas during the incubation in $\mathrm{mL} / \mathrm{gVS}$. The experiment was produced in triplicate, and the results displayed are the mean values of the 3 replicates with their associated standard deviations as error bars.

The advantages of $\mathrm{CO}_{2}$ sequestration associated with the cultivation of macroalgae are also significant. Typically, the utilisation of 1 tonne of macroalgae sequesters 6 times the amount of $\mathrm{CO}_{2}$ emitted during the processing, maintenance and transport of the feedstock [32], and the close proximity of macroalgae farms to sources of pollution can improve their growth rate, while cleaning the water of excess nutrients [30]. Macroalgae also have a high level of marco nutrients, improving the digestate as a biofertilizer [30] [33]. Finally, the C:N ratio desired for optimal anaerobic digestion is between 20:1 - 30:1 [34], where a ratio bellow 15:1 can result in excess levels of ammonia in the anaerobic digestion process, leading to unstable biogas production [35]. The C:N ratio of $S$. latissima has been observed to be $22: 1$, suggesting that it is an ideal substrate for anaerobic digestion [11].

Despite this, it should be noted that the impact of the extensive harvesting of wild macroalgae in these regions is unknown and may cause local ecological issues. The turnover of macroalgae in Nordic regions is relatively high, but excessive removal of macroalgae from the seabed in a specific area could result in the collapse of the community, which may take several years to recover. Alternative methods of industrial-scale growth could avoid these drawbacks, by the growth of macroalgae on suspended systems in deeper waters. If the waters are deep enough, there would be a limited amount of wild macroalgae present in the area; however, microalgae would then be competing for light with these artificial systems, and their growth could be reduced. 


\section{Conclusion}

The research undertaken in this study has presented the potential for utilisation of a common macroalgae (S. latissima) present in the Nordic coastal regions for production of biomethane through a straight-forward pre-treatment, followed by anaerobic digestion. The biomethane yield obtained with the enzymatically hydrolysed algae suggests a potentially of $1760 \mathrm{~m}^{3}$ of biomethane per ha of productive sea floor could be obtained. This implies that $S$. latissima could provide a significant biomass source from the production of biomethane in the Nordic regions. Furthermore, the rate increase observed in biogas production as a result of the enzymatic hydrolysis allows for a shorter retention time in continuous feed anaerobic digesters, increasing the potential biogas yield over time. The Nordic coastlines provide a natural, untapped area for biomass production that could be maintained in a sustainable manner. Not only would the continual harvesting and natural cultivation of macroalgae from the sea floor help mitigate the rising levels of dissolved carbon in the oceans, but it would also increase the production of the non-fossil fuel biogas due to the larger variety of excessable biomass sources.

\section{Acknowledgements}

Jacob J. Lamb acknowledges the support from the ENERSENSE research initiative, and his research was supported by funding from the Norwegian University of Science and Technology-NTNU.

\section{Conflicts of Interest}

The authors declare no conflicts of interest regarding the publication of this paper.

\section{References}

[1] Ashokkumar, V., Salim, M.R., Salam, Z., Sivakumar, P., Chong, C.T., Elumalai, S. et al. (2017) Production of Liquid Biofuels (Biodiesel and Bioethanol) from Brown Marine Macroalgae Padina Tetrastromatica. Energy Conversion and Management, 135, 351-361. https://doi.org/10.1016/j.enconman.2016.12.054

[2] Xu, J. and Li, M. (2017) Innovative Technological Paradigm-Based Approach towards Biofuel Feedstock. Energy Conversion and Management, 141, 48-62. https://doi.org/10.1016/j.enconman.2016.04.075

[3] Chen, H., Zhou, D., Luo, G., Zhang, S. and Chen, J. (2015) Macroalgae for Biofuels Production: Progress and Perspectives. Renewable \& Sustainable Energy Reviews, 47, 427-437. https://doi.org/10.1016/j.rser.2015.03.086

[4] Su, Y., Zhang, P. and Su, Y. (2015) An Overview of Biofuels Policies and Industrialization in the Major Biofuel Producing Countries. Renewable \& Sustainable Energy Reviews, 50, 991-1003. https://doi.org/10.1016/j.rser.2015.04.032

[5] Marchetti, J.M., Miguel, V.U. and Errazu, A.F. (2007) Possible Methods for Biodiesel Production. Renewable \& Sustainable Energy Reviews, 11, 1300-1311. https://doi.org/10.1016/j.rser.2005.08.006 
[6] Noraini, M.Y., Ong, H.C., Badrul, M.J. and Chong, W.T. (2014) A Review on Potential Enzymatic Reaction for Biofuel Production from Algae. Renewable \& Sustainable Energy Reviews, 39, 24-34. https://doi.org/10.1016/j.rser.2014.07.089

[7] Rawat, I., Kumar, R.R., Mutanda, T. and Bux, F. (2013) Biodiesel from Microalgae: A Critical Evaluation from Laboratory to Large Scale Production. Applied Energy, 103, 444-467. https://doi.org/10.1016/j.apenergy.2012.10.004

[8] Singh, A. and Olsen, S.I. (2011) A Critical Review of Biochemical Conversion, Sustainability and Life Cycle Assessment of Algal Biofuels. Applied Energy, 88, 35483555. https://doi.org/10.1016/j.apenergy.2010.12.012

[9] Lamare, M.D. and Wing, S.R. (2001) Calorific Content of New Zealand Marine Macrophytes. New Zealand Journal of Marine and Freshwater Research, 35, 335-341. https://doi.org/10.1080/00288330.2001.9517004

[10] Msuya, F.E. and Neori, A. (2008) Effect of Water Aeration and Nutrient Load Level on Biomass Yield, N Uptake and Protein Content of the Seaweed Ulva lactuca Cultured in Seawater Tanks. Journal of Applied Phycology, 20, 1021-1031. https://doi.org/10.1007/s10811-007-9300-6

[11] Jard, G., Marfaing, H., Carrère, H., Delgenes, J.P., Steyer, J.P. and Dumas, C. (2013) French Brittany Macroalgae Screening: Composition and Methane Potential for Potential Alternative Sources of Energy and Products. Bioresource Technology, 144, 492-498. https://doi.org/10.1016/j.biortech.2013.06.114

[12] Kumar, S., Gupta, R., Kumar, G., Sahoo, D. and Kuhad, R.C. (2013) Bioethanol Production from Gracilaria verrucosa, a Red Alga, in a Biorefinery Approach. Bioresource Technology, 135, 150-156. https://doi.org/10.1016/j.biortech.2012.10.120

[13] Sahoo, D., Elangbam, G. and Devi, S.S. (2012) Using Algae for Carbon Dioxide Capture and Biofuel Production to Combat Climate Change. Phykos, 42, 32-38.

[14] Kraan, S. (2013) Mass-Cultivation of Carbohydrate Rich Macroalgae, a Possible Solution for Sustainable Biofuel Production. Mitigation and Adaptation Strategies for Global Change, 18, 27-46. https://doi.org/10.1007/s11027-010-9275-5

[15] Horn, S.J. (2009) Seaweed Biofuels: Production of Biogas and Bioethanol from Brown Macroalgae. VDM, Verlag Dr. Müller.

[16] Peinado, I., Girón, J., Koutsidis, G. and Ames, J.M. (2014) Chemical Composition, Antioxidant Activity and Sensory Evaluation of Five Different Species of Brown Edible Seaweeds. Food Research International, 66, 36-44. https://doi.org/10.1016/j.foodres.2014.08.035

[17] Lamb, J.J., Sarker, S., Hjelme, D.R. and Lien, K.M. (2018) Fermentative Bioethanol Production Using Enzymatically Hydrolysed Saccharina latissima. Advances in Microbiology, 8, 378. https://doi.org/10.4236/aim.2018.85025

[18] Dubois, M., Gilles, K.A., Hamilton, J.K., Rebers, P.A. and Smith, F. (1956) Colorimetric Method for Determination of Sugars and Related Substances. Analytical Chemistry, 28, 350-356. https://doi.org/10.1021/ac60111a017

[19] Miller, G.L. (1959) Use of Dinitrosalicylic Acid Reagent for Determination of Reducing Sugar. Analytical Chemistry, 31, 426-428.

https://doi.org/10.1021/ac60147a030

[20] Ometto, F., Steinhovden, K.B., Kuci, H., Lunnbäck, J., Berg, A., Karlsson, A., et al. (2018) Seasonal Variation of Elements Composition and Biomethane in Brown Macroalgae. Biomass and Bioenergy, 109, 31-38. https://doi.org/10.1016/j.biombioe.2017.11.006

[21] Ekstrand, E.-M., Larsson, M., Truong, X.-B., Cardell, L., Borgstrom, Y., Björn, A., et 
al. (2013) Methane Potentials of the Swedish Pulp and Paper Industry-A Screening of Wastewater Effluents. Applied Energy, 112, 507-517. https://doi.org/10.1016/j.apenergy.2012.12.072

[22] Association, A.P.H., Association, A.W.W., Federation, W.P.C. and Federation, W.E. (1915) Standard Methods for the Examination of Water and Wastewater. American Public Health Association, Vol. 2.

[23] Schiener, P., Black, K.D., Stanley, M.S. and Green, D.H. (2015) The Seasonal Variation in the Chemical Composition of the Kelp Species Laminaria digitata, Laminaria hyperborea, Saccharina latissima and Alaria esculenta. Journal of Applied Phycology, 27, 363-373. https://doi.org/10.1007/s10811-014-0327-1

[24] Ravanal, M.C., Sharma, S., Gimpel, J., Reveco-Urzua, F.E., Øverland, M., Horn, S.J., et al. (2017) The Role of Alginate Lyases in the Enzymatic Saccharification of Brown Macroalgae, Macrocystis pyrifera and Saccharina latissima. Algal Research, 26, 287-293. https://doi.org/10.1016/j.algal.2017.08.012

[25] Sharma, S. and Horn, S.J. (2016) Enzymatic Saccharification of Brown Seaweed for Production of Fermentable Sugars. Bioresource Technology, 213, 155-161. https://doi.org/10.1016/j.biortech.2016.02.090

[26] Gupta, R., Sharma, K.K. and Kuhad, R.C. (2009) Separate Hydrolysis and Fermentation (SHF) of Prosopis juliflora, a Woody Substrate, for the Production of Cellulosic Ethanol by Saccharomyces cerevisiae and Pichia stipitis-NCIM 3498. Bioresource Technology, 100, 1214-1220. https://doi.org/10.1016/j.biortech.2008.08.033

[27] Kuhad, R.C., Gupta, R., Khasa, Y.P. and Singh, A. (2010) Bioethanol Production from Lantanacamara (Red Sage): Pretreatment, Saccharification and Fermentation. Bioresource Technology, 101, 8348-8354. https://doi.org/10.1016/j.biortech.2010.06.043

[28] Kuhad, R.C., Mehta, G., Gupta, R. and Sharma, K.K. (2010) Fed Batch Enzymatic Saccharification of Newspaper Cellulosics Improves the Sugar Content in the Hydrolysates and Eventually the Ethanol Fermentation by Saccharomyces cerevisiae. Biomass and Bioenergy, 34, 1189-1194. https://doi.org/10.1016/j.biombioe.2010.03.009

[29] Adams, J.M.M., Toop, T.A., Donnison, I.S. and Gallagher, J.A. (2011) Seasonal Variation in Laminaria digitata and Its Impact on Biochemical Conversion Routes to Biofuels. Bioresource Technology, 102, 9976-9984. https://doi.org/10.1016/j.biortech.2011.08.032

[30] Allen, E., Wall, D.M., Herrmann, C., Xia, A. and Murphy, J.D. (2015) What Is the Gross Energy Yield of Third Generation Gaseous Biofuel Sourced from Seaweed? Energy, 81, 352-360. https://doi.org/10.1016/j.energy.2014.12.048

[31] Handå, A., Forbord, S., Broch, O.J., Richardsen, R., Skjermo, J. and Reitan, K.I. (2009) Dyrking og anvendelse av tare, med spesiell fokus på bioenergi i nordområdene. Sintef Rep SFH80 A, 92036.

[32] Alvarado-Morales, M., Boldrin, A., Karakashev, D.B., Holdt, S.L., Angelidaki, I. and Astrup, T. (2013) Life Cycle Assessment of Biofuel Production from Brown Seaweed in Nordic Conditions. Bioresource Technology, 129, 92-99. https://doi.org/10.1016/j.biortech.2012.11.029

[33] Tarwadi, S.J. and Chauhan, V.D. (1987) Seaweed Biomass as a Source of Energy. Energy, 12, 375-378. https://doi.org/10.1016/0360-5442(87)90107-1

[34] Allen, E., Browne, J., Hynes, S. and Murphy, J.D. (2013) The Potential of Algae Blooms to Produce Renewable Gaseous Fuel. Waste Management, 33, 2425-2433. 
https://doi.org/10.1016/j.wasman.2013.06.017

[35] Allen, E., Browne, J.D. and Murphy, J.D. (2013) Evaluation of the Biomethane Yield from Anaerobic Co-Digestion of Nitrogenous Substrates. Environmental Technology, 34, 2059-2068. https://doi.org/10.1080/09593330.2013.806564 